\title{
Potential causes for the unequal contribution of picophytoplankton to total biomass and productivity in oligotrophic waters
}

\author{
Emilio Fernández ${ }^{1, *}$, Emilio Marañón ${ }^{1}$, Xosé Anxelu G. Morán ${ }^{2}$, Pablo Serret ${ }^{1}$ \\ ${ }^{1}$ Facultad de Ciencias, Departamento de Ecología y Biología Animal, Universidad de Vigo, Campus Lagoas-Marcosende, \\ 36200 Vigo, Spain \\ ${ }^{2}$ Instituto Español de Oceanografía, Centro Oceanográfico de Xixón, Camín de l'Arbeyal s/n, 33212 Xixón, Spain
}

\begin{abstract}
Size-fractionated chlorophyll $a$ and primary production measurements during 7 latitudinal cruises (56 stations) in the Atlantic Ocean indicate that in subtropical and tropical regions the relative contribution of large (L) $(>2 \mu \mathrm{m})$ phytoplankton to total (T) chlorophyll a biomass (B) is smaller (BL:BT ratio $=0.25 \pm 0.01 \mathrm{SE}$ ) than their contribution to total primary production (P) (PL:PT ratio $=0.45 \pm 0.02$ ). This implies a lower assimilation number for picoplankton than for larger cells: $1.5 \pm 0.2$ and $3.7 \pm 0.3 \mathrm{mg} \mathrm{C} \mathrm{mg} \mathrm{chlorophyll} a \mathrm{~h}^{-1}$, respectively $(\mathrm{n}=90)$. During short-term time-course experiments in subtropical and tropical waters of the North Atlantic, a $>50 \%$ reduction in the abundance of picoplankton, mainly Prochlorococcus spp., took place as early as the first $2 \mathrm{~h}$ of incubation. This suggests that long incubation times in bottle experiments can lead to underestimations of primary production rates, at least in oligotrophic waters. The phytoplankton size-structure remained fairly constant throughout the experiments, suggesting that the high PL:PT ratios in these environments cannot be due to enhanced loss rates of small-sized phytoplankton as a result of bottle enclosure. Our results indicate that the observed disagreement between BL:BT and PL:PT ratios is not necessarily an experimental artifact, but could be related to a higher light utilization efficiency of larger phytoplankton.
\end{abstract}

KEY WORDS: Primary production - Size-fractionated chlorophyll · Picoplankton · Oligotrophic waters · Atlantic Ocean

Resale or republication not permitted without written consent of the publisher

\section{INTRODUCTION}

Quantification of the amount of inorganic carbon photosynthetically incorporated by open-ocean primary producers has been and still remains a central activity in most oceanographic research programmes focussed on understanding biogeochemical cycling in the upper ocean, despite the well-known limitations inherent in the ${ }^{14} \mathrm{C}$ incorporation method (e.g. Lean \& Burnison 1979, Peterson 1980). Some of these limitations largely derive from the in vitro methodological approach (e.g. Gieskes et al. 1979), although a variety of additional potential sources of error have been reported, such as cell breakage during filtration (Goldman \& Dennett 1985), dark ${ }^{14} \mathrm{C}$ uptake (Markager
1998), contamination by the Niskin samplers (Williams \& Robertson 1989), incubation starting time (Mingelbier et al. 1994) or the effect of dissolved organic C released during the experiments (Karl et al. 1998).

More recently, a large amount of information has accumulated on the size distribution of primary production in different marine environments (e.g. Tremblay \& Legendre 1994, Legendre \& Rassoulzadegan 1996, among others). Phytoplankton size, a variable under hydrodynamical control (Rodríguez et al. 2001), has been hypothesized to play a keystone role in conceptual models of energy transfer through pelagic food webs (Legendre \& Le Févre 1989). Several observational and modelling efforts have provided evidence of the functional relationship between the size-structure 
of primary producers and a diversity of central processes in the functioning of pelagic ecosystems, such as new and export production (e.g. Legendre \& Rassoulzadegan 1996, Tremblay et al. 1997, Legendre \& Michaud 1998) or dissolved organic carbon (DOC) production and net community production rates (Teira et al. 2001). Also, most of the pelagic ecosystem models developed in the last few years are size-structured (e.g. Fasham et al. 1999, Hurtt \& Armstrong 1999). However, only a small fraction of the available sizefractionated phytoplankton data has been obtained from open-ocean waters (e.g. Platt et al. 1983, Joint et al. 1992, Jochem \& Zeitschel 1993). In a recent paper, Marañón et al. (2001) summarised the main patterns of size-fractionated chlorophyll a ( $\mathrm{chl} a$ ) and primary production of the Atlantic Ocean from $50^{\circ} \mathrm{N}$ to $50^{\circ} \mathrm{S}$ and pointed out a discrepancy between the relative contribution of small-sized phytoplankton cells to total chl a and $\mathrm{C}$ incorporation rates, particularly in oligotrophic ecological domains. These authors reported that in these environments the contribution of $<2 \mu \mathrm{m}$ cells to total primary production was considerably lower than to total chl a (see Table 1 and Fig. 10A in Marañón et al. 2001). Several alternative but not exclusive explanations can be put forward: (1) enclosure of picoplankton in the incubation bottles enhances their loss rates to a higher extent than those of larger phytoplankton, and thus the finding would be an artifact originated from chl a being measured at the start of primary production experiments whose duration typically exceeds $2 \mathrm{~h}_{\text {; }}(2)>2 \mu \mathrm{m}$ phytoplankton cells have higher assimilation numbers than smaller cells; and (3) the C:chl $a$ ratio is size-dependent, being higher in smaller cells.

In this investigation, we first present further evidence supporting what seems to be a general discrepancy between the fraction of carbon incorporated by small-sized phytoplankton cells and the corresponding contribution to total chl a concentration. We then consider the results of 2 short-term time-series experiments conducted in subtropical and tropical Atlantic waters with the aim of exploring the potential causes of such discrepancy and to test whether phytoplankton biomass, size-structure and production change during incubation.

\section{MATERIALS AND METHODS}

The data presented in this paper were obtained during 7 oceanographic cruises in open oceanic waters of the Atlantic Ocean from $50^{\circ} \mathrm{N}$ to $20^{\circ} \mathrm{S}$ : AMT-2 (September and October 1995), AMT-3 (April 1996), AMT4 (September and October 1996), AMT-5 (April 1997), Azores-2 (April 1999), AMT-11 (September and October 2000) and CIRCANA-1 (November 2001).
On each cruise, size-fractionated chl a concentrations and primary production rates were measured as described in detail by Marañón et al. (2001). Briefly, $250 \mathrm{ml}$ water samples collected from 5 to 7 depths with Niskin bottles were filtered sequentially through 20, 2 and $0.2 \mu \mathrm{m}$ polycarbonate filters. After extraction with $90 \%$ acetone at $4^{\circ} \mathrm{C}$ overnight, the chl a fluorescence was determined with a 10 SU Turner Designs Fluorometer calibrated with pure chl $a$.

For primary production measurements, 3 clear and 1 black acid-cleaned $70 \mathrm{ml}$ polypropylene bottles were filled with seawater collected from 5 to 6 depths with Niskin bottles within $2 \mathrm{~h}$ after sunrise. After addition of 370 to $740 \mathrm{kBq}\left(10\right.$ to $20 \mu \mathrm{Ci}$ ) of $\mathrm{NaH}^{14} \mathrm{CO}_{3}$, each bottle was incubated at irradiances similar to those experienced by the cells at their original sampling depths in an on-deck incubator refrigerated with surface seawater and provided with neutral-density screens. Incubations lasted for 6 to $7 \mathrm{~h}$, except on Cruise AMT-11, when they extended for a $24 \mathrm{~h}$ period. After incubation, samples were filtered at very low vacuum pressure $(<50 \mathrm{~mm} \mathrm{Hg})$ through 20,2 and $0.2 \mu \mathrm{m}$ polycarbonate filters, which were decontaminated after exposure to concentrated $\mathrm{HCl}$ fumes for $12 \mathrm{~h}$. Filters were then placed into vials and $4 \mathrm{ml}$ of scintillation cocktail were added. Radioactivity of the samples was measured on a Beckman LS6000 SC counter (AMT cruises) or with a LKB Winspectral 1414 liquid scintillation counter (Azores-2 and CIRCANA-I cruises). The averaged coefficient of variation of the photic-depthintegrated size-fractionated primary production rates presented in this study were $11,10,16$ and $8 \%$ for the 0.2 to 2,2 to $20,>20 \mu \mathrm{m}$ and total primary production, respectively.

Two time-series experiments were conducted in oligotrophic waters of the North Atlantic Ocean during the CIRCANA-1 cruise to assess the evolution of sizefractionated chl $a$, size-fractionated primary production and the biomass of picoplankton groups during $24 \mathrm{~h}$ periods. Water samples were collected from $3 \mathrm{~m}$ depth with Niskin bottles at $23^{\circ} 35^{\prime} \mathrm{N}, 28^{\circ} 00^{\prime} \mathrm{W}$ (Expt 1) and $14^{\circ} 32^{\prime} \mathrm{N}, 28^{\circ} 00^{\prime} \mathrm{W}$ (Expt 2) on 2 and 4 November 2001, respectively: 15 to 18 polypropylene bottles $(70 \mathrm{ml})$ were filled and placed in an on-deck incubator at sea surface irradiance levels and refrigerated with surface seawater. Incubations started at 11:45 h and 10:40 h, respectively. At selected time intervals ( 5 for Expt 1 and 6 for Expt 2), 3 bottles were drawn from the incubators and processed for the determination of size-fractionated chl $a$ as described above. Samples $(1 \mathrm{ml})$ for the quantification of the carbon biomass of Prochlorococcus spp., Synechococcus spp. and small eukaryotic algae were drawn from the same bottles and immediately analysed in vivo with a Becton \& Dickinson FACSCalibur flow cytometer. We added $1 \mu \mathrm{m}$ fluorescent latex 
beads (Molecular Probes) as internal standard, and the 3 picoplanktonic groups were distinguished by their different signals in plots of red and orange fluorescence versus side scatter. For each group, picophytoplankton abundance was converted into biomass with the average cellular carbon content estimates given by Zubkov et al. (1998) for a latitudinal transect along the Atlantic Ocean.

For the determination of carbon incorporation rates, 16 to 20 polypropylene bottles $(70 \mathrm{ml})$ were filled with the seawater sample, inoculated with the radiocarbon label and incubated on deck. At each time interval, 3 clear and 1 black bottles were drawn from the incubator and size-fractionated primary production rates were measured following the methodological protocol described above.

\section{RESULTS AND DISCUSSION}

To illustrate the observed discrepancy between the relative contribution of large-sized phytoplankton cells to total chl a and to total C incorporation rates in oligotrophic environments, the latitudinal variability of the photic zone-integrated ratios BL:BT ( $>2 \mu \mathrm{m}$ chl a:total chl a) and PL:PT (>2 $\mu \mathrm{m}$ C incorporation rate:total $\mathrm{C}$ incorporation rate) measured on Cruise AMT-11 is presented in Fig. 1. The contribution of $>2 \mu \mathrm{m}$ phytoplankters to total chl a biomass was $>40 \%$ in the northernmost latitudes and at some stations within the equatorial region $\left(10^{\circ} \mathrm{N}\right.$ to $\left.10^{\circ} \mathrm{S}\right)$. In these regions, the fraction contributed by these 2 size classes to the total biomass was close to their contribution to primary production. However, in the subtropical regions of both hemispheres, $>2 \mu \mathrm{m}$ cells, while representing on average $<30 \%$ of total chl a biomass, accounted for up to $50 \%$ of total $\mathrm{C}$ incorporation. The best example of this mismatch was in the Southern Atlantic Subtropical Gyre, and especially at $18^{\circ} 45^{\prime} \mathrm{S}$, where $>2 \mu \mathrm{m}$ cells contributed 24 and $67 \%$ of total chl a and primary production, respectively.

These observations, however, are not unique to the AMT-11 cruise. We assembled the photic zone-integrated size-fractionated chl $a$ and primary production data from the stations located in open-ocean subtropical and tropical waters $\left(35^{\circ} \mathrm{N}\right.$ to $\left.33^{\circ} \mathrm{S}\right)$ which were visited during the 7 cruises, and plotted a production-biomass (P-B) diagram as originally proposed by Tremblay \& Legendre (1994). Although showing a considerable scatter, all 56 data

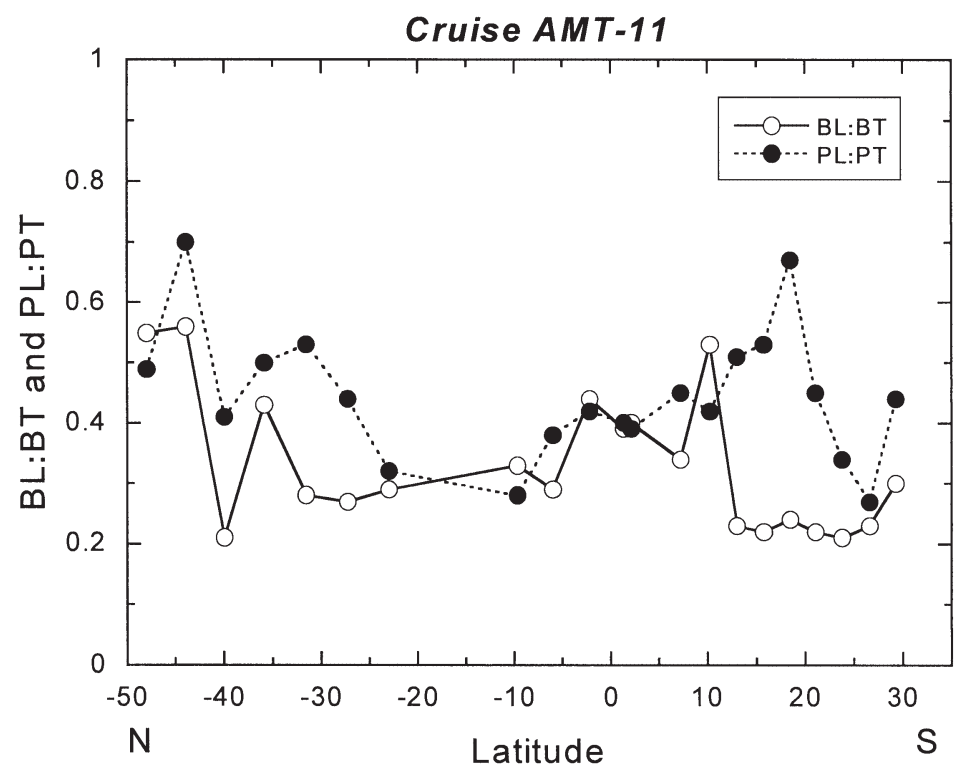

Fig. 1. Latitudinal distribution of ratios large phytoplankton biomass:total phytoplankton biomass (BL:BT) ( $>2 \mu \mathrm{m}$ chl a:total chl a) and large phytoplankton production:total phytoplankton production (PL:PT) ( $>2 \mu \mathrm{m}$ C incorporation rate:total $\mathrm{C}$ incorporation rate) on Cruise AMT-11 (September and October 2000)

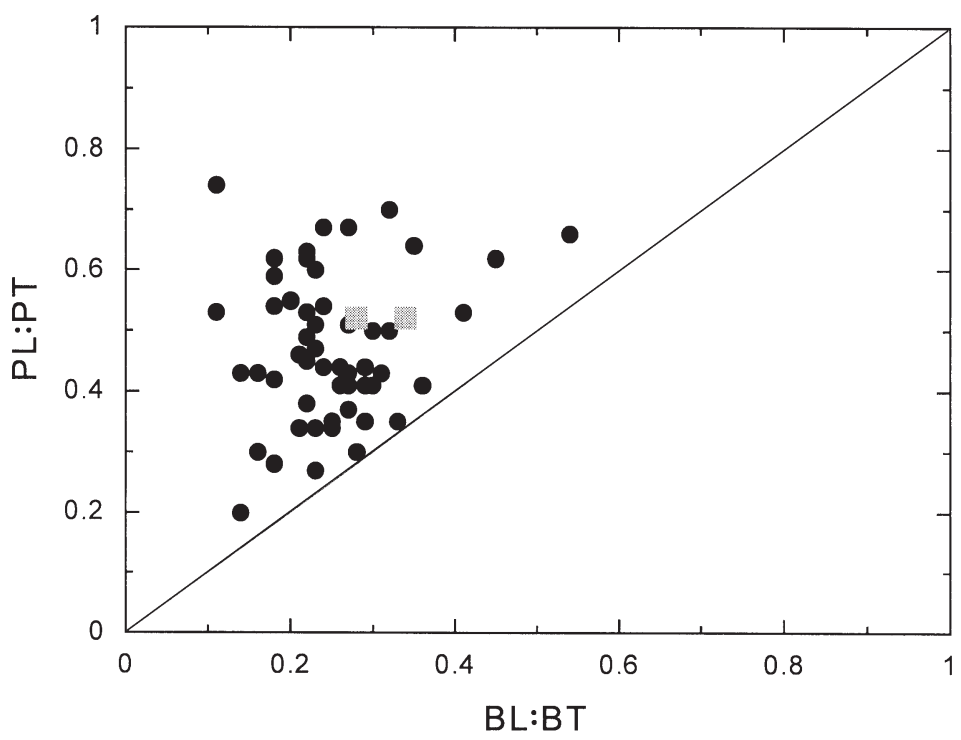

Fig. 2. BL:BT vs PL:PT relationships (for abbreviations see Fig. 1) for subtropical and tropical Atlantic Ocean during Cruises AMT-2, AMT-3, AMT-4, AMT-5, AMT-11, Azores-2 and CIRCANA-1 (n = 56). Grey squares indicate stations where the short-term time-series experiments were carried out

points fell within the upper left corner of the diagram (Fig. 2), i.e. for every single station, the relative contribution of $>2 \mu \mathrm{m}$ phytoplankton to $\mathrm{C}$ incorporation was higher than its contribution to total chl $a$. The averaged $\mathrm{BL}: \mathrm{BT}$ and PL:PT ratios were $0.25 \pm 0.01(\mathrm{SE})$ and $0.45 \pm 0.02$, respectively. 
The significance of the results presented so far relies on the assumption that the carbon to chlorophyll ratios of the 2 size-fractions under study are similar. Marañon et al. (2000) calculated the relationship between phytoplankton chl a and carbon for a data set collected during 2 of the cruises included in our study (cruises AMT-2 and AMT-3) and an additional latitudinal cruise carried out in April 1995 (AMT-1) (see their Fig. 8). These authors found that the phytoplankton carbon to chl a ratio did not show statistically significant variations among the different ecological domains visited, which were in turn characterised by a largely different phytoplankton size-structure. Previous investigations using an extensive data base had reached a similar conclusion from the analysis of the carbon to chl a ratio of small and large phytoplankton assemblages (Tremblay \& Legendre 1994), although higher carbon to chl a ratios have been also reported for small cells (Malone 1980) and in oligotrophic waters (Buck et al. 1996, Chavez et al. 1996)

While a similar pattern for the distribution of the BL:BT and PL:PT ratios had been described earlier for subtropical waters (Malone 1993), this finding is not exclusively restricted to permanently oligotrophic environments, given that it has also been reported for polar (Legendre et al. 1993) and temperate environments (Tamigneaux et al. 1999). It has been suggested that this pattern results from a preferential removal of larger cells in oligotrophic areas by sinking and grazing processes (Tremblay \& Legendre 1994). In temperate and upwelling regions, the BL:BT and PL:PT ratios are generally of the same magnitude (Marañón et al. 2001).

We explored the magnitude of the mismatch between size-fractionated biomass and production in 5 open-ocean ecological domains using a data set consisting of all the depth-integrated data collected from temperate, subtropical, tropical and equatorial regions of the Atlantic Ocean during the 7 cruises, comprising a total of 106 stations. We calculated the photic zoneintegrated (BL:BT)/(PL:PT) ratio, which indicates the degree of mismatch between the relative contribution of each phytoplankton size-fraction to total biomass and production (Table 1). For all regions, the averaged (BL:BT)/(PL:PT) ratio was $<1$, indicating that the relative contribution of $>2 \mu \mathrm{m}$ phytoplankton to total primary production exceeded their corresponding contribution to biomass. Nevertheless, the average values of this ratio were significantly lower in subtropical and tropical waters than in temperate environments (ANOVA, $F_{1,78}=11.07, \mathrm{p}<0.05$ ). One possible reason for this difference could be an experimental artifact affecting preferentially small cells, since picoplankton dominates the biomass of autotrophs in open-ocean oligotrophic waters. If so, most size-fractionated primary production measurements taken in these environments could be severely biased.

To determine the reason for the difference we conducted 2 time-series experiments to assess whether the observed mismatch in the BL:BT and PL:PT ratios could be explained by differential losses of the picoplankton component relative to larger phytoplankton inside the incubation bottles. This would result in a progressive decrease from 1 of the (BL:BT)/(PL:PT) ratio with increasing incubation time. In principle, this is a plausible hypothesis, as it has been experimentally established that the grazing pressure of protists upon small-sized phytoplankton in oligotrophic environments can account for more than $80 \%$ of the total amount of carbon fixed by primary producers (Lessard \& Murrell 1998, Quevedo \& Anadón 2001). In addition, evidence of very high rates of cellular lysis, an alternative loss process, has been also reported for oligotropic waters (Agustí et al. 1998). If preferential loss of picoplankton biomass were the cause of the mismatch, we would expect a decrease in total chl a concentration during incubation associated with a reduction in the picoplankton biomass relative to the total photoautotrophic biomass.

The initial phytoplankton populations were dominated by picoplankton cells in both time-series experiments:

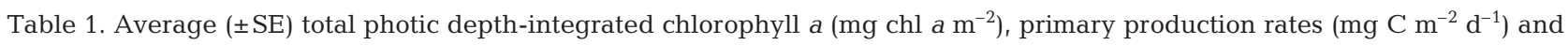
ratios large phytoplankton biomass:total phytoplankton biomass, BL:BT ( $>2 \mu \mathrm{m}$ chl a:total chl a), large phytoplankton production:total phytoplankton production, PL:PT ( $>2 \mu \mathrm{m} \mathrm{C}$ incorporation rate:total C incorporation rate) and (BL:BT)/(PL:PT) in 5 Atlantic ecological domains

\begin{tabular}{|lccccc|}
\hline Variable & $\begin{array}{c}\text { Temperate } \\
(\mathrm{n}=20)\end{array}$ & $\begin{array}{c}\text { Subtropical } \mathrm{N} \\
(\mathrm{n}=25)\end{array}$ & $\begin{array}{c}\text { Tropical } \\
(\mathrm{n}=14)\end{array}$ & $\begin{array}{c}\text { Equatorial } \\
(\mathrm{n}=27)\end{array}$ & $\begin{array}{c}\text { Subtropical S } \\
(\mathrm{n}=20)\end{array}$ \\
\hline Total chl $a$ & $24.3 \pm 2.2$ & $18.7 \pm 1.4$ & $26.1 \pm 1.9$ & $27.8 \pm 1$ & $25.5 \pm 2.6$ \\
Total primary production & $416 \pm 59$ & $193 \pm 15$ & $236 \pm 34$ & $427 \pm 60$ & $247 \pm 23$ \\
BL:BT & $0.33 \pm 0.02$ & $0.28 \pm 0.02$ & $0.25 \pm 0.02$ & $0.26 \pm 0.02$ & $0.24 \pm 0.02$ \\
PL:PT & $0.43 \pm 0.03$ & $0.46 \pm 0.02$ & $0.49 \pm 0.03$ & $0.35 \pm 0.02$ & $0.46 \pm 0.03$ \\
(BL:BT)/(PL:PT) & $0.84 \pm 0.06$ & $0.62 \pm 0.04$ & $0.57 \pm 0.09$ & $0.74 \pm 0.04$ & $0.57 \pm 0.06$ \\
\hline
\end{tabular}




\section{Expt 1}
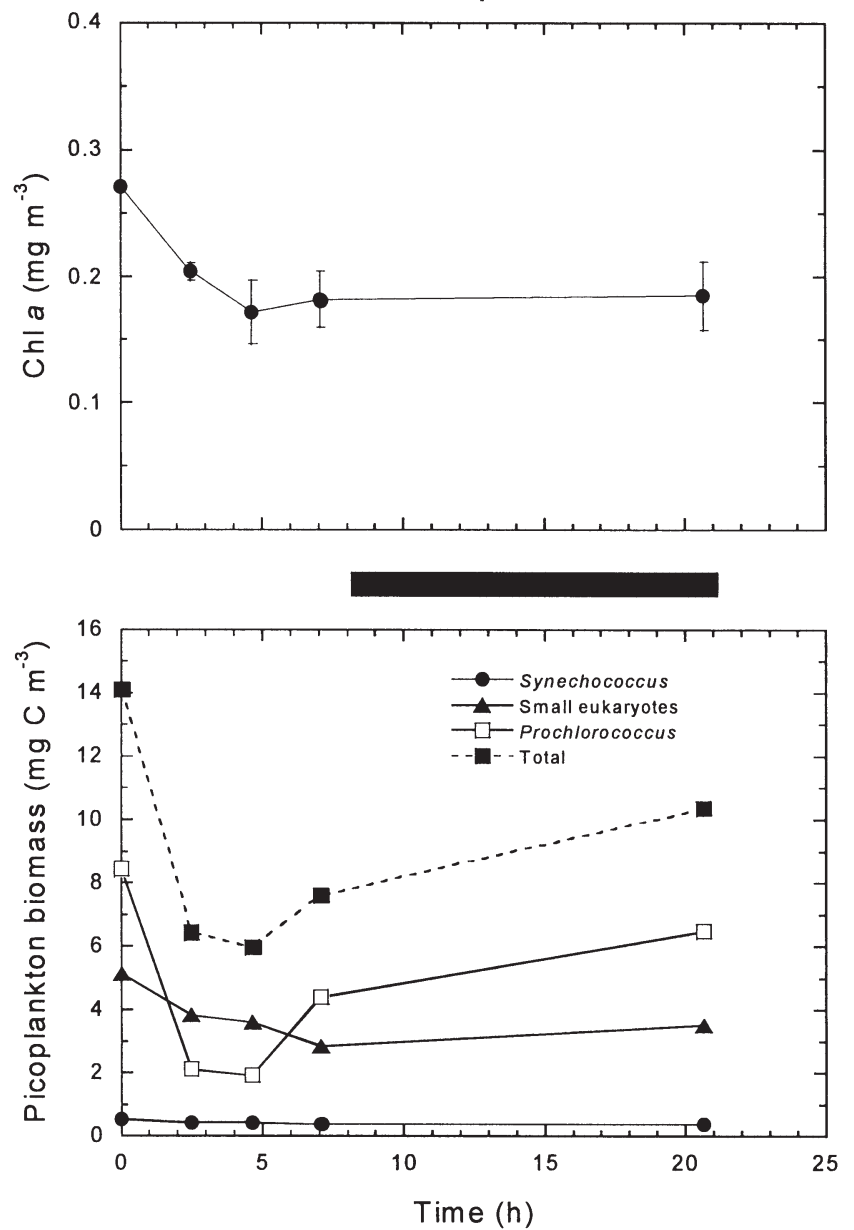

Expt 2
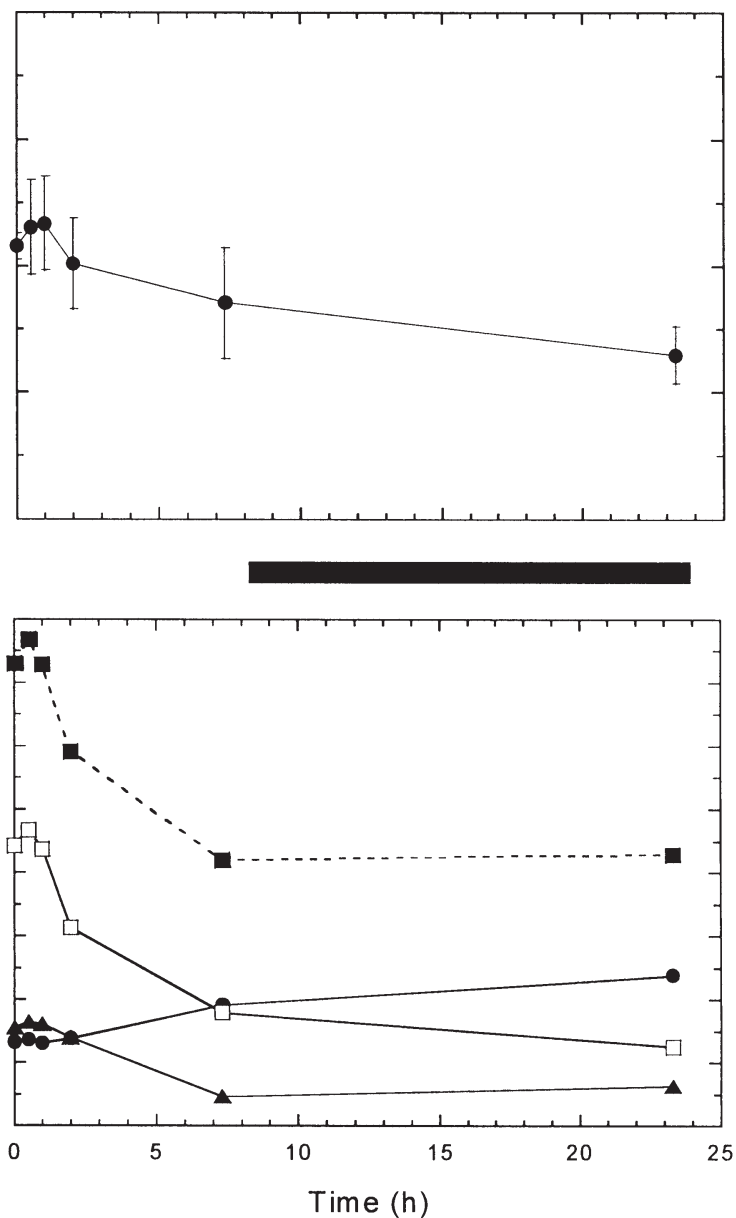

Fig. 3. Short-term time variation in total chl a and carbon biomass of Prochlorococcus spp., Synechococcus spp. and small eukaryotes in surface $(5 \mathrm{~m})$ samples from oligotrophic waters of the North Atlantic along longitude $28^{\circ} 00^{\prime} \mathrm{W}$ in Expt $1\left(23^{\circ} 35^{\prime} \mathrm{N}\right)$ and Expt $2\left(14^{\circ} 32^{\prime} \mathrm{N}\right)$. Black bars under $X$-axis indicate dark incubation period

the initial contribution of $<2 \mu \mathrm{m}$ cells to total chlorophyll was 59 and $68 \%$, respectively. A similar decline was found in the evolution of total chl $a$ in the 2 experiments (Fig. 3). In Expt 1, total chl a concentration decreased by $37 \%$ in the first $2 \mathrm{~h}$ and then remained quite constant until the end of the experiment. In Expt 2, after a slight increase during the first hour, total chl a concentration decreased by 7 and $21 \%$ of initial values in the first $2 \mathrm{~h}$ and 7 h 20 min incubation, respectively. These sharp changes in chl a concentration over relatively short timescales were never observed in surface fluorescence readings obtained at fixed positions sampled over $30 \mathrm{~h}$ periods in the subtropical NE Atlantic. The evolution of the biomass of picoplankton groups was consistent with the changes detected in total chl a (Fig. 3). In Expt 1, the picoplankton community was initially dominated by Prochlorococcus. After the first $2.5 \mathrm{~h}$, the carbon biomass of Prochlorococcus spp. had been dramatically reduced by $75 \%$, while that of Synechococcus spp. and small eukaryotes had diminished by 22 and $25 \%$, respectively. Total small phytoplankton biomass recovered to some extent from $7 \mathrm{~h}$ onwards as a result of an increase in Prochlorococcus biomass. In contrast, the biomass of small eukaryotic cells decreased steadily during the light period. In Expt 2, Prochlorococcus was also the most important picoplankter in terms of biomass, but Synechococcus had a higher biomass compared to the previous experiment. Prochlorococcus biomass increased very slightly during the first $30 \mathrm{~min}$ of incubation; after the first $2 \mathrm{~h}$ it had decreased by $29 \%$ and after the first 7 h by $59 \%$. Synechococcus biomass followed an almost opposite trend: after remaining approximately constant for the first hour, it progressively increased by $79 \%$, and by the end of the experiment this species had become the most relevant picoplankton group in terms of biomass. 
No consistent pattern of photoacclimation was observed during the incubation period for any picoplanktonic group, as evidenced by the time-course of the average red fluorescence relative to that of latex beads (data not shown). However, increases in the mean cytometric flow signals of relative side scatter (a surrogate of cell size) and red fluorescence detected at the end of the light period in some groups (e.g. Prochlorococcus and small eukaryotes in Expt 1, Synechococcus in Expt 2) could indicate nocturnal cell growth prior to division. The initial increase in loss processes (i.e. grazing, lysis) relative to growth in both experiments resulted in noticeable differences in the contributions of the respective groups to picoplankton carbon after $24 \mathrm{~h}$, illustrating the difficulty of predicting the evolution of phytoplankton populations in long incubations.

As stated in 'Materials and methods', the sampling procedure adopted in oceanographic cruises typically involves the collection of samples for determination of chl a before the start of the primary production experiments. According to our results, even short incubation periods $(2 \mathrm{~h})$, are sufficient to reveal sharp reductions in total chl a and small phytoplankton biomass, a trend that could potentially in itself explain the differences observed in the BL:BT and PL:PT ratios recorded by current measurement methods (i.e. measuring BL:BT at the beginning and PL:PT at the end of incubation). However, in order to support the hypothesis of a preferential loss of small primary producers, a progressive increase in the relative contribution of $>2 \mu \mathrm{m}$ cells to total phytoplankton biomass should occur as incubation proceeds. We did not detect any significant change in BL:BT or PL:PT throughout either of the 2 experiments (Fig. 4); i.e. despite the decrease in picoplankton biomass, the chlorophyll size-structure of the phytoplankton assemblage remained unchanged, suggesting that $>2 \mu \mathrm{m}$ phytoplankton may also be subject to loss rates similar to those in small-sized cells. It should be mentioned that most $<2 \mu \mathrm{m}$ cells in both experiments corresponded to Prochlorococcus $\left(\sim 10^{5}\right.$ cells $\left.\mathrm{ml}^{-1}\right)$ and Synechococcus $\left(\sim 10^{3}\right.$ and $\sim 10^{4}$ cells $\mathrm{ml}^{-1}$, in Expts 1 and 2, respectively) and that at least some of the small eukaryotic cells detected using the flow cytometer might be $>2 \mu \mathrm{m}$. The use of a larger volume incubation bottle would probably alter the observed primary production results (Gieskes et al. 1979), but this investigation did not test the effect of bottle volume.

A higher PL:PT than BL:BT ratio also implies that the assimilation number of picoplankton assemblages is lower than that of larger cells. In fact, the primary production to chlorophyll ratio (P:chl a) for $<2 \mu \mathrm{m}$ and $>2 \mu \mathrm{m}$ cells was $1.0 \pm 0.1$ and $5.1 \pm 0.3 \mathrm{mg} \mathrm{C} \mathrm{mg}^{-1} \mathrm{chl} \mathrm{a}$ $\mathrm{h}^{-1}$, respectively, for Expt 1 and $4.7 \pm 0.3$ and $6.6 \pm$ $0.5 \mathrm{mg} \mathrm{C} \mathrm{mg}^{-1} \mathrm{chl} \mathrm{a} \mathrm{h}^{-1}$ for Expt 2. We calculated this ratio for all the upper mixed-layer samples included in the data set in Fig. 2 ( $\mathrm{n}=90)$, and found that the average P:chl a ratio of small $(<2 \mu \mathrm{m})$ and large $(>2 \mu \mathrm{m})$ phytoplankton was $1.5 \pm 0.2$ and $3.7 \pm 0.3$, respectively. Higher assimilation numbers associated with larger cells (mainly diatoms) have also been reported for phytoplankton assemblages in the subarctic Pacific (Hashimoto \& Shiomoto 2002). Similar results were also found in coastal phytoplankton communities both during microcosms experiments (Madariaga \& Fernández 1990) and under natural conditions at sea (Han
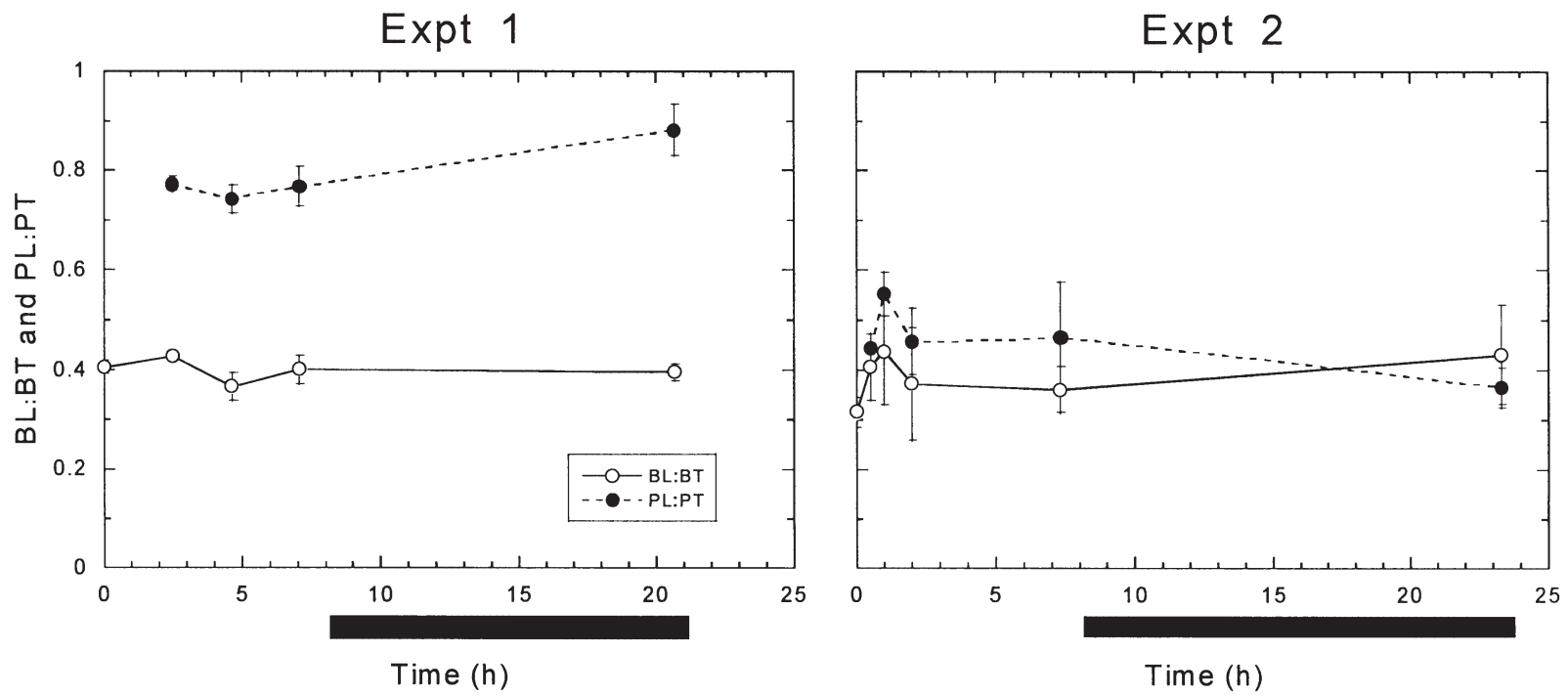

Fig. 4. Short-term time variation in BL:BT and PL:PT ratios (for abbreviations see Fig. 1 ) in surface (5 m) samples from oligotrophic waters of the North Atlantic along longitude $28^{\circ} 00^{\prime} \mathrm{W}$ in Expt $1\left(23^{\circ} 35^{\prime} \mathrm{N}\right)$ and Expt $2\left(14^{\circ} 32^{\prime} \mathrm{N}\right)$. Black bars under $x$-axis indicate dark incubation period 
\& Furuya 2000), although these results could partially be the result of the experimental procedure, which involved removal of large grazers from the incubation bottles.

Our results showing higher production to chl a ratios in the larger size fraction are unexpected in view of the current understanding of sizedependent variability in resource acquisition and photon-harvesting capacities of phytoplankton. Other things being equal, smaller cells have a smaller package effect and a higher surface to volume ratio, and therefore are able to use resources more efficiently and attain higher growth rates than larger phytoplankton (Raven 1998). Indeed, size-fractionated P-E experiments typically show that both light-saturated photosynthesis per unit chl a $\left(P^{\mathrm{B}} \mathrm{m}\right)$ and the rate of photosynthetic activity $(\alpha)$ tend to be higher in picophytoplankton than in the larger size classes (e.g. Platt et al. 1983, Joint \& Pomroy 1986, Frenette et al. 1996 among others), but only a few such measurements are conducted in the oligotrophic open ocean. Although at present we cannot explain why our measurements consistently indicated a higher photosynthetic efficiency for larger phytoplankton, it is likely that taxonomic differences played a role. In this context, it has been noted that diatom growth rates display a somewhat weaker size dependence than other algal groups (Chisholm 1992). The presence in these oligotrophic regions of diatoms and other eukaryotic algae characterised by relatively high photosynthetic efficiencies could explain our results. However, only a thorough survey of the geographical variability in the photosyntetic parameters of size-fractionated phytoplankton can provide a definite answer to this problem.

An additional implication derived from our results is that primary production rates could be underestimated when $>2 \mathrm{~h}$ incubations are adopted (Table 2), at least in the open-ocean oligotrophic environments in which our experiments were conducted. In Expt 1, $4 \mathrm{~h} 40 \mathrm{~min}$ and $7 \mathrm{~h} 05$ min after the beginning of incubation, carbon incorporation rates had decreased by 20 and $45 \%$, respectively, compared to rates measured after $2 \mathrm{~h}$. In Expt 2, these rates decreased less, with primary production being only $16 \%$ lower after 7 h 20 min incubation than after $2 \mathrm{~h}$ incubation. However, when shorter incubation times are used, a slight stimulation of carbon incorporation rates can occur, as shown in Expt 2, which illustrates the diversity of responses associated with the confinement of plankton assemblages in bottles. Hourly primary production rates were enhanced by $5 \%$ after $1 \mathrm{~h}$ incubation compared to $2 \mathrm{~h}$ incubations, which translates into an 8 and $5 \%$ increase in total chl a concentration and picoplankton
Table 2. Hourly phytoplankton carbon incorporation rates and irradiance-normalized carbon incorporation rates measured during short-term $(24 \mathrm{~h})$ time-series experiments in subtropical $\left(23^{\circ} 35^{\prime} \mathrm{N}\right.$, $28^{\circ} 00^{\prime} \mathrm{W}$; Expt 1 ) and tropical (14 $32^{\prime} \mathrm{N}, 28^{\circ} 00^{\prime} \mathrm{W}$; Expt 2 ) waters of the North Atlantic Ocean

\begin{tabular}{|lcc|}
\hline $\begin{array}{l}\text { Incubation } \\
\text { period } \\
(\mathrm{h}: \mathrm{min})\end{array}$ & $\begin{array}{c}\mathrm{C} \text { incorporation rate } \\
\left(\mathrm{mg} \mathrm{C} \mathrm{m}^{-3} \mathrm{~h}^{-1}\right)\end{array}$ & $\begin{array}{c}\text { Irradiance-normalized } \\
\mathrm{C} \text { incorporation rate } \\
\left(\mu \mathrm{C} \mathrm{m}^{-3} \mathrm{~h}^{-1}\left(\mu \mathrm{E} \mathrm{m}^{-2} \mathrm{~s}^{-1}\right)^{-1}\right)\end{array}$ \\
\hline Expt 1 & & \\
$2: 30$ & $0.69 \pm 0.06$ & $1.92 \pm 0.16$ \\
$4: 40$ & $0.50 \pm 0.05$ & $1.08 \pm 0.10$ \\
$7: 05$ & $0.38 \pm 0.06$ & $0.84 \pm 0.13$ \\
Expt 2 & & \\
30 min & $1.04 \pm 0.13$ & $1.60 \pm 0.20$ \\
$1: 00$ & $1.23 \pm 0.31$ & $1.79 \pm 0.45$ \\
$2: 00$ & $1.17 \pm 0.15$ & $1.70 \pm 0.22$ \\
$7: 20$ & $0.98 \pm 0.25$ & $1.43 \pm 0.37$ \\
\hline
\end{tabular}

biomass, respectively. These temporal changes were not due to variations in the light levels experienced by the incubated phytoplankton populations (Table 2), since the production data were corrected by taking into account the integrated irradiance during each time interval. In this context, several authors have reported positive net phytoplankton growth rates in long-term incubations using the dilution method in oligotrophic waters (e.g. Stelfox-Widdicombe et al. 2000, Quevedo \& Anadón 2001); however, these rates showed a large degree of spatial variability and, in some experiments, negative net growth rates were measured (see Fig. 2 in Quevedo \& Anadón 2001).

In the light of our results, it seems advisable when working in open-ocean oligotrophic regions to run $\mathrm{chl} a$ analyses also at the end of the carbon uptake and oxygen-exchange bottle experiments and, whenever possible, to monitor cell numbers in parallel incubations. Importantly, the averaged primary production rates reported herein for oligotrophic biogeochemical provinces (Table 1) compare well with those reported by Longhurst et al. (1995) for the same regions (260 and $210 \mathrm{mg} \mathrm{C} \mathrm{m}^{-2} \mathrm{~d}^{-1}$ for subtropical North Atlantic and subtropical South Atlantic, respectively), which are derived from remotely sensed chl a data and the parameters of the photosynthesis-irradiance relationship. This similarity leads us to believe that the potential underestimation of photosynthetic carbon incorporation rates pointed out in the present study could possibly extend to independent measurements previously conducted in the oligotrophic Atlantic.

The results presented herein show that in temperate, subtropical, tropical and equatorial regions of the Atlantic Ocean, depth-integrated PL:PT is always higher than BL:BT and that the magnitude of the mismatch between both ratios depends on the biogeo- 
graphic region considered. According to our observations, the disagreement between BL:BT and PL:PT ratios cannot be simply considered an experimental artifact related to a more efficient removal of small cells by protists as a result of enclosure. The significant decrease in picoplankton that takes place during the first $2 \mathrm{~h}$ of the incubation period cannot in itself explain the enhanced PL:PT ratio observed in these environments, and alternative explanations must be put forward, such as the lower assimilation number characteristic of picoplankton assemblages. A higher PL:PT ratio with respect to BL:BT could also be interpreted in terms of preferential removal of larger cells in oligotrophic areas (Tremblay \& Legendre 1994); however, our experiments did not include grazing or sedimentation measurements. We cannot disregard the possibility that different results might be obtained were the initial phytoplankton populations used for the experiments characterised by a lower (BL:BT)/(PL:PT) ratio, i.e. a higher degree of mismatch between both ratios (see positions of data points for the 2 experimental stations in the B-P plot in Fig. 2), since in such a situation loss rates are likely to have a stronger effect on phytoplankton size-structure. If our results are confirmed in other oceanic waters, then the picoplankton dominance of autotrophic biomass throughout vast areas of the world ocean cannot be taken as an indication of an equal degree of dominance in terms of primary production rates.

Acknowledgements. This work was supported by the MCyT project CIRCANA (MAR1999-1072-C03-01) and the speical action (REN2001-3973-E).

\section{LITERATURE CITED}

Agustí SP, Satta MP, Mura P, Benavent E (1998) Dissolved esterase activity as a tracer of phytoplankton lysis: evidence of high phytoplankton lysis rates in the NW Mediterranean. Limnol Oceanogr 43:1836-1849

Buck KR, Chavez FP, Campbell L (1996) Basin-wide distributions of living carbon components and the inverted trophic pyramid of the central gyre of the North Atlantic Ocean, summer 1993. Aquat Microb Ecol 10:283-298

Chavez FP, Buck KR, Service SK, Newton J, Barber RT (1996) Phytoplankton variability in the central and eastern tropical Pacific. Deep-Sea Res II 43:835-870

Chisholm SW (1992) Phytoplankton size. In: Falkowski PG, Woodhead AD (eds) Primary productivity and biogeochemical cycles in the sea. Plenum Press, New York, p 213-217

Fasham MJ, Boyd PW, Savidge G (1999) Modeling the relative contributions of autotrophs and heterotrophs to carbon flow at a Lagrangian JGOFS stations in the northeast Atlantic: the importance of DOC. Limnol Oceanogr 44: 80-94

Frenette JJ, Demers S, Legendre L, Boulé M (1996) Sizerelated photosynthetic characteristics of phytoplankton during periods of seasonal mixing in an oligotrophic multibasin lake system. J Plankton Res 18:45-61
Gieskes WW, Kraay GW, Baars MA (1979) Current ${ }^{14} \mathrm{C}$ methods for measuring primary production: gross underestimates in oceanic waters. Neth J Sea Res 13:58-78

Goldman JC, Dennett MR (1985) Susceptibility of some marine phytoplankton species to cell breakage during filtration and post-filtration rinsing. J Exp Mar Biol Ecol 86:47-58

Han M, Furuya K (2000) Size and species-specific primary productivity and community structure of phytoplankton in Tokio Bay. J Plankton Res 22:1221-1235

Hashimoto S, Shiomoto A (2002) Light utilization efficiency of size-fractionated phytoplankton in the subarctic Pacific, spring and summer 1999: high effciency of large-sized diatom. J Plankton Res 24:83-87

Hurtt GC, Armstrong RA (1999) A pelagic ecosystem model calibrated with BATS and OWSI data. Deep-Sea Res 46: 27-61

Jochem FJ, Zeitzschel B (1993) Productivity regime and phytoplankton size structure in the tropical and subtropical North Atlantic in spring 1989. Deep-Sea Res 40:495-519

Joint IR, Pomroy A (1986) Photosynthetic characteristics of nanoplankton and picoplankton from the surface mixed layer. Mar Biol 92:465-474

Joint IR, Pomroy A, Savidge G, Boyd P (1992) Size-fractionated primary productivity in the northeast Atlantic in May-July 1989. Deep-Sea Res II 40:423-440

Karl DM, Hebel DV, Bjorkman K (1998) The role of dissolved organic matter release in the productivity of the oligotrophic North Pacific Ocean. Limnol Oceanogr 43: 1270-1286

Lean DSR, Burnison BK (1979) An evaluation of errors in the ${ }^{14} \mathrm{C}$ method of primary production measurement. Limnol Oceanogr 24:917-928

Legendre L, Le Févre J (1989) Hydrodynamical singularities as controls of recycled versus export production in oceans. In: Berger WH, Smetacek VS, Wefer G (eds) Productivity of the ocean: present and past. John Wiley \& Sons, Chichester, p 49-63

Legendre L, Michaud J (1998) Flux of biogenic carbon in oceans: size-dependent regulation by pelagic food webs. Mar Ecol Prog Ser 164:1-11

Legendre L, Rassoulzadegan F (1996) Food-web mediated export of biogenic carbon in oceans: hydrodynamic control. Mar Ecol Prog Ser 145:179-193

Legendre L, Gosselin M, Hirche HJ, Kattner G, Rosenberg G (1993) Environmental control and potential fate of sizefractionated phytoplankton in the Greenland Sea $\left(75^{\circ} \mathrm{N}\right)$. Mar Ecol Prog Ser 98:297-313

Lessard EJ, Murrell MC (1998) Microzooplankton herbivory and phytoplankton growth in the northwestern Sargasso Sea. Aquat Microb Ecol 16:173-188

Longhurst A, Sathyendranath S, Platt T, Caverhill C (1995) An estimate of global primary production in the ocean from satellite radiometer data. J Plankton Res 17:1245-1271

Madariaga I, Fernández E (1990) Photosynthetic carbon metabolism of size-fractionated phytoplankton during an experimental bloom in marine microcosms. J Mar Biol Assoc UK 70:531-543

Malone TC (1980) Algal size. In: Morris I (ed) The physiological ecology of phytoplankton. Blackwell Scientific Publications, London, p 433-463

Malone TC (1993) Size-fractionated primary productivity of marine phytoplankton. In: Falkowski PG (ed) Primary productivity of the sea. Plenum Press, New York, p 301-309

Marañón E, Holligan PM, Varela M, Mouriño B, Bale AJ (2000) Basin-scale variability of phytoplankton biomass, production and growth in the Atlantic Ocean. Deep-Sea Res 47:825-857 
Marañón E, Holligan PM, Barciela R, González N, Mouriño B, Pazó MJ, Varela M (2001) Patterns of phytoplankton size structure and productivity in contrasting open-ocean environments. Mar Ecol Prog Ser 216:43-56

Markager S (1998) Dark uptake of inorganic ${ }^{14} \mathrm{C}$ in oligotrophic oceanic waters. J Plankton Res 20:1813-1836

Mingelbier M, Klein B, Claereboudt MR, Legendre L (1994) Measurements of daily primary production using $24 \mathrm{~h}$ incubations with the ${ }^{14} \mathrm{C}$ method: a caveat. Mar Ecol Prog Ser 113:301-309

Peterson BJ (1980) Aquatic primary productivity and the ${ }^{14} \mathrm{C}$ $\mathrm{CO}_{2}$ method: a history of the productivity problem. Annu Rev Ecol Syst 11:359-385

Platt T, Subba Rao DV, Irwin B (1983) Photosynthesis of picoplankton in the oligotrophic ocean. Nature 301: 702-704

Quevedo M, Anadón R (2001) Protist control of phytoplankton growth in the subtropical north-east Atlantic. Mar Ecol Prog Ser 221:29-38

Raven JA (1998) The twelfth Tansley lecture. Small is beautiful: the picophytoplankton. Funct Ecol 12:503-513

Rodríguez J, Tintoré J, Allen JT, Blanco JM and 6 others (2001) Mesoscale vertical motion and the size structure of phytoplankton in the ocean. Nature 410:360-363

Editorial responsibility: Otto Kinne (Editor),

Oldendorf/Luhe, Germany
Stelfox-Widdicombe CE, Edwards ES, Burkill PH, Sleigh MA (2000) Microzooplankton grazing activity in the temperate and subtropical NE Atlantic: summer 1996. Mar Ecol Prog Ser 208:1-12

Tamigneaux E, Legendre L, Klein B, Mingelbier M (1999) Seasonal dynamics and potential fate of size-fractionated phytoplankton in a temperate nearshore environment (Western Gulf of St. Lawrence, Canada). Estuar Coast Shelf Sci 48:253-269

Teira E, Pazó MJ, Serret P, Fernández E (2001) Dissolved organic carbon production by microbial populations in the Atlantic Ocean. Limnol Oceanogr 46:1370-1377

Tremblay JE, Legendre L (1994) A model for the size-fractionated biomass and production of marine phytoplankton. Limnol Oceanogr 39:2004-2014

Tremblay JE, Klein B, Legendre L, Rivkin RB, Therriault JC (1997) Estimation of $f$-ratios in oceans based on phytoplankton size structure. Limnol Oceanogr 42(3):595-601

Williams PJleB, Robertson JI (1989) A serious inhibition problem from a Niskin sampler during plankton productivity studies. Limnol Oceanogr 34:1300-1305

Zubkov MV, Sleigh MA, Tarran GA, Burkill PH, Leakey RJG (1998) Picoplanktonic community structure on an Atlantic transect from $50^{\circ} \mathrm{N}$ to $50^{\circ} \mathrm{S}$. Deep-Sea Res 45:1339-1355

Submitted: June 28, 2002; Accepted: February 11, 2003 Proofs received from author(s): May 2, 2003 